\title{
Chest circumference in full-term newborns: how can it be predicted?
}

Ingrid G. Azevedo ${ }^{1}$, Norrara S. O. Holanda ${ }^{2}$, Nivia M. R. Arrais ${ }^{3,4}$, Raweny T. G. Santos ${ }^{2}$, Ana G. F. Araujo ${ }^{5}$ and

Silvana A. Pereira ${ }^{5,6^{*}}$ (D)

\begin{abstract}
Background: Although over the years a number of studies have used chest circumference (CC) as a sensitive tool to identify the health status of infants, a particularly important aspect for this population is the lack of data on normal values and prediction equations. In order to facilitate and validate the interpretation of CC data in newborn (NB), the aim was to study the relation between CC and other anthropometric variables and develop a predictive equation for CC in a population of full-term newborns.

Methods: Cross-sectional study, carried out with full-term infants. The anthropometric (CC, head circumference - HC, length, age and weight) and hemodynamic variables were evaluated during the first $24 \mathrm{~h}$ of life. Bivariate analysis was performed between CC and HC, weight, length and type of delivery, followed by multiple linear regression analysis, including variables that were significant in the bivariate analysis. For data analysis, we used the SPSS program, considering $p<0.05$ and $95 \% \mathrm{Cl}$.

Results: The birth weight of the 120 NB varied between 2580 and $4225 \mathrm{~g}$ (mean $3360 \mathrm{~g}$ ) and the gestational age between 37 and 42 weeks (mean 39 weeks). Approximately $61 \%$ of the sample were delivered vaginally and 67 (56\%) were boys. The variables that remained statistically associated with CC after multivariate analysis were weight ( $\beta 0.003$, Cl: $0.002: 0.003, p=0.001)$ and $\mathrm{HC}(\beta$ 0.287, Cl: $0.156: 0.417, p=0.001)$. For the linear regression model, the predictive equation of CC was $14.87+(0.003 \times$ weight $)+(0.287 \times \mathrm{HC})$, with a prediction of $76 \%$.
\end{abstract}

Conclusion: The results show a positive correlation between $C \mathrm{C}$ and weight, length and $\mathrm{HC}$, and based on the linear regression model, the predictive equation for CC is based only on weight and HC.

Keywords: Chest circumference, Newborns, Development, Predictive equation

\section{Background}

Assessment in perinatology uses anthropometry as an essential tool to monitor growth and evaluate the nutritional and functional status of newborns (NB). It is an economical, non-invasive and easy-to-execute tool that can improve understanding of growth patterns and their variations [1].

Studies in different populations suggest the use of anthropometric parameters is an important substitute

\footnotetext{
* Correspondence: apsilvana@ccs.ufrn.br

${ }^{5}$ Postgraduated Program in Rehabilitation Science - FACISA - UFRN, Santa Cruz, Brazil

${ }^{6}$ Department of Physical therapy and Postgraduated Program in Rehabilitation Science - FACISA, Federal University of Rio Grande do Norte UFRN, Campus Universitário Lagoa Nova - CEP 59078-970, Natal, RN Caixa Postal 1524, Brazil

Full list of author information is available at the end of the article
}

for early identification of low-weight newborns [2-4]. Of these variables, head circumference $(\mathrm{HC})$, chest circumference (CC) and abdominal circumference (AC) exhibit good correlation with the health status and well-being of children and are widely used as indicators of health, performance and survival $[5,6]$.

$\mathrm{CC}, \mathrm{HC}$ and $\mathrm{AC}$ are simple, reliable and logistically viable tools in field conditions that can be used on a large scale in both domiciliary care and high-complexity environments due to their accessibility. These resources, whose aim is early detection of developmental changes and prevention of newborn deaths [2], are important methods, capable of predicting the need for early referral of low-birth-weight babies for extra care, given that after surviving the critical neonatal period, they may experience compromised physical and mental growth [2]. 
In a study involving NB hospitalized in a neonatal intensive care unit (NICU), Hadush, Berhe \& Medhanyie, 2017 [7] demonstrated that birth weight showed a strong correlation with anthropometric variables (CC and $\mathrm{HC}$ ). In this study, conducted in Ethiopia, $\mathrm{CC}$ and $\mathrm{HC}$ were used to identify low-birth-weight newborns. The cutoff points for better sensitivity and specificity identified in the study were $30 \mathrm{~cm}$ and $31 \mathrm{~cm}$ for $\mathrm{CC}$ and $\mathrm{HC}$, respectively, the former being the best predictor of low birth weight [7].

Asian studies also showed $\mathrm{CC}<30 \mathrm{~cm}$ and arm circumference $<8.7 \mathrm{~cm}$, with better sensitivity and specificity in identifying low-birth-weight NB $[2,8]$. Alternative measures to identify low birth weight have been recommended by the World Health Organization (WHO) [9] since the last decade. Furthermore, it is important to consider that CC is easier to measure, because the nipple line can be clearly and objectively established as a reference point, making its identification operationally feasible when compared to $\mathrm{HC}$, or even a scale to estimate weight [7].

Although over the years a number of studies have used CC as a sensitive tool to identify the health status of infants, establishing a good reference for clinical practice in neonatology $[10,11]$, a particularly important aspect for this population is the lack of data on normal values and prediction equations.

Thus, in order to facilitate and validate the interpretation of CC data in NB, the aim was to study the relation between $\mathrm{CC}$ and other anthropometric variables and develop a predictive equation for $\mathrm{CC}$ in a population of full-term newborns.

\section{Methods}

This is a cross-sectional observational study, conducted at Ana Bezerra University Hospital, located in Northeastern Brazil, between April and November 2017. The medical-assistance service, which provides dedicated prepartum and postpartum care for the mother-infant dyad promotes maternal-infant bonding, where both remain close to each other and are cared for by a multiprofessional team. There are 51 licensed beds, 9 delivery rooms and the postpartum nursery can accommodate up to 32 beds. The Neonatal Intensive Care Unit (NICU) provides quality care for high-risk newborn infants free of charge and can accommodate up to 10 beds. The neonatal team consists of 10 staff physicians and 4 rotating pediatric residents, 10 nurses, 4 physical therapists, 3 nutritionists, 2 speech therapists and 7 multiprofessional residents.

A convenience sample of $151 \mathrm{NB}$ was recruited, based on the adequate gestational age (GA) (37 to 42 weeks) [12], of both sexes, at up to $23 \mathrm{~h}$ of life, spontaneous breathing full-term $\mathrm{NB}$, hemodynamically stable and exhibiting no chest deformities. We have used WHO child growth pattern, which shows physical growth curves, achievement windows and performance milestones [12]. In this sense, the z-score of height for age was considered, considering the positive $(+)$ or negative (-) value depending on whether the child's real height is higher or lower than the median height of the WHO reference population at that age for that sex. Children with values found within the median of the WHO reference population were considered for the study.

The anthropometric variables birth weight, $\mathrm{CC}, \mathrm{HC}$ and length were measured according to the Brazilian Pediatric Society's Orientation Manual [13] and corroborating the methodology described in studies by HADUSH; BERHE; MEDHANYIE, 2017 [7]. The measures of $\mathrm{CC}$ and $\mathrm{HC}$ were obtained with a nonstretchable tape measure while NB were in the supine position; to assess $\mathrm{CC}$, the tape was wrapped around the head midway on the occipital bone, and for $\mathrm{HC}$, the tape was wrapped under the axillary area around the back to meet at the mid-sternal area at the nipple level.

The hemodynamic variables heart rate (HR), systolic (SBP) and diastolic blood pressure (DBP) were measured using a DIXTAL DX $2022^{\circ}$ multiparametric monitor with the NB lying on a bed with a suitable cuff (width corresponding to $2 / 3$ of arm length, extension to $1 / 2$ of its diameter) placed on the left arm. Respiratory rate (RR) was measured by observing chest expansion, counting the number of breaths per minute. The 1 and 5-min Apgar scores and type of delivery were recorded on the medical chart. All the variables were assessed during the first $24 \mathrm{~h}$ of life in the company of the newborn's mother or guardian.

The data collected were analyzed using the Statistical Package for the Social Sciences (SPSS) program, version 21.0 (SPSS for Windows, Chicago, USA). The Kolmogorov-Sminorv test was applied to determine data normality. Descriptive statistics for all the variables were expressed as mean and standard deviation, according to sex, and analyzed using the Mann-Whitney test for quantitative variables and the chi-squared test for categorical variables. Bivariate analyses were carried out applying simple linear regression. The multiple linear regression model was used to determine the correlation between $\mathrm{CC}$ and the significant covariables in the bivariate analysis $(p<0.05)$. For all the stages, we considered $\mathrm{p}<0.05$ and CI 95\%. Moreover, regression diagnoses were conducted for all linear analyses, including collinearity tests, with no significant deviations.

\section{Results}

A total of $151 \mathrm{NB}$ were assessed and 31 were excluded due to sleepiness and persistent crying. The final 
sample consisted of $120 \mathrm{NB}$, with birth weight varying between $2580 \mathrm{~g}$ and $4225 \mathrm{~g}$ (mean $3360 \mathrm{~g}$ ) and GA between 37 and 42 weeks (average of 39 weeks). Approximately $61 \%$ of the sample were born vaginally and 67 (56\%) were boys. There was no statistical difference between hemodynamic measures and RR, or type of delivery, when the sample was considered separately by sex, as shown in Table 1. However, weight, length, HC and $\mathrm{CC}$ were higher in the boys, exhibiting a statistically significant difference.

Table 2 shows the bivariate analysis between CC and the following variables: type of delivery, weight, length and HC. There was no statistical difference between CC and type of delivery, but it was significant for length, weight and $\mathrm{HC}$.

When the significant bivariate analysis variables were included in the multiple linear regression analysis, only weight and $\mathrm{HC}$ remained as predictors of $\mathrm{CC}$, as exhibited in Table 3.

From the regression model, the predictive equation of $\mathrm{CC}$ is $14.87+(0.003 \mathrm{x}$ weight $)+(0.287 \times \mathrm{HC})$.

\section{Discussion}

Monitoring and assessing NB development is essential to promoting health and preventing complications, thereby guaranteeing higher newborn survival rates $[14,15]$. Healthy growth is reflected in a physical increase in body size, measured in centimeters or grams, and results in a rise in the number and size of cells and in their degree of cellular differentiation, for the development and execution of organic and functional activity [16]. These events occur simultaneously to

Table 1 Newborns characteristics $(n=120)$, Santa Cruz Brazil - 2017

\begin{tabular}{llll}
\hline & $\begin{array}{l}\text { Boys }(n=67) \\
\mathrm{n}(\%) / \text { Mean (SD) }\end{array}$ & $\begin{array}{l}\text { Girls }(n=53) \\
\mathrm{n}(\%) / \text { Mean (SD) }\end{array}$ & $p$-value \\
\hline Weight (g) & $3360.22 \pm 365.36$ & $3142.24 \pm 356.82$ & $0.003^{\mathrm{a}}$ \\
Length (cm) & $49.18 \pm 2.20$ & $47.67 \pm 2.21$ & $<0.001^{\mathrm{a}}$ \\
GA (weeks) & $39.20 \pm 1.20$ & $39.05 \pm 1.35$ & $0.428^{\mathrm{a}}$ \\
HR (bpm) & $126.40 \pm 16.19$ & $129.88 \pm 20.70$ & $0.564^{\mathrm{a}}$ \\
RR (brpm) & $48.71 \pm 9.01$ & $46.33 \pm 8.89$ & $0.223^{\mathrm{a}}$ \\
SBP (mmHg) & $122.58 \pm 17.29$ & $126.45 \pm 21.34$ & $0.248^{\mathrm{a}}$ \\
DBP (mmHg) & $47.01 \pm 10.42$ & $45.83 \pm 9.07$ & $0.682^{\mathrm{a}}$ \\
CC (cm) & $34.13 \pm 1.46$ & $33.51 \pm 1.39$ & $0.036^{\mathrm{a}}$ \\
HC (cm) & $34.80 \pm 1.35$ & $34.18 \pm 0,89$ & $0.006^{\mathrm{a}}$ \\
Type of delivery & & & $0.157^{\mathrm{b}}$ \\
\multicolumn{1}{c}{ Vaginal } & $37(55.2)$ & $36(67.9)$ & \\
\multicolumn{1}{c}{ Cesarean } & $30(44.8)$ & $17(32.1)$ &
\end{tabular}

$a$ Mann-Whitney, $b$ Chi-squared, $g$ gram, $c m$ centimeter, bpm beats per minute, brpm breaths per minute, $m m H G$ millimeters of mercury, $G A$ gestational age, $H R$ heart rate, $R R$ respiratory rate, $S B P$ systolic blood pressure, $D B P$ diastolic blood pressure, $C C$ chest circumference, $H C$ head circumference
Table 2 Bivariate analysis of newborns chest circumference values according to sample characteristics $(n=120)$, Santa Cruz Brazil - 2017

\begin{tabular}{lll}
\hline & $\beta(C 195 \%)$ & $p$-value \\
\hline Type of Delivery & $-0.094(-0.591: 0.403)$ & $0.708^{\mathrm{a}}$ \\
Weight & $0.003(0.002: 0.003)$ & $<0.01^{\mathrm{a}}$ \\
Length & $0.300(0.199: 0.400)$ & $<0.01^{\mathrm{a}}$ \\
Head Circumference & $0.764(0.634: 0.895)$ & $<0.01^{\mathrm{a}}$ \\
\hline
\end{tabular}

${ }^{\mathrm{a}}$ simple linear regression

preserve and maintain harmonious relations at the same magnitude and proportion of brain, spine, rib cage, and limb development, in addition to other body segments $[17,18]$.

The circumferences measured separately in the present study are within normal ranges [12], showing a positive correlation between $\mathrm{CC}$, length and $\mathrm{HC}$, regardless of sex, with weight and $\mathrm{HC}$ as the main predictors of CC.

In the present study, the newborns exhibited adequate weight for gestational age, and satisfactory $\mathrm{HC}$ and $\mathrm{CC}$, with higher measures in the group of boys. However, the difference in $\mathrm{CC}$ between the girls and boys was not statistically significant, and similar to normal growth patterns reported in the literature [6].

In a longitudinal study, Jaldin et al. [10] assessed CC growth in exclusively breastfed children in their first 6 months of life. These authors obtained higher $\mathrm{CC}$ values in boys, albeit not exceeding $1 \mathrm{~cm}$ above the average for the age under study, corroborating the present study. Breastfeeding is very important for newborns to ensure adequate CC growth, as well as routine monitoring of children aged between 0 and 24 months, the period of greatest post-natal growth [10, 11, 13-23].

Streja et al. [24] conducted a study on the weight/CC ratio at birth and assessed $\mathrm{NB}$ growth according to maternal factors in the intrauterine period of fetal development, observing body disproportionality in newborns that were small for gestational age, in terms of weight, $\mathrm{CC}$ and $\mathrm{AC}$. These measures are considered developmental markers, based on the condition of the newborn, considering that the mother's condition and her life habits are determinants of neonatal growth $[25,26]$.

From this standpoint, it is important to underscore each child's individual development pattern, which

Table 3 Multiple linear regression model for variables associated with newborns CC $(n=120)$, Santa Cruz - Brazil 2017

\begin{tabular}{lll}
\hline Variables & Adjusted $\beta(\mathrm{Cl} 95 \%)$ & $p$-value \\
\hline Weight $(\mathrm{g})$ & $0.003(0.002: 0.003)$ & $<0.001$ \\
Head Circumference $(\mathrm{cm})$ & $0.287(0.156: 0.417)$ & $<0.001$
\end{tabular}

$\mathrm{g}$ gram, $\mathrm{cm}$ centimeter, $\mathrm{Cl}$ confidence interval 
consists of an intrinsic relationship between the newborn's intrinsic and extrinsic factors, since the infant undergoes a series of transitions from intrauterine to extrauterine life. In this perspective, a contextualized assessment of the level and quality of NB development and formulation of predictive equations are indispensable [27-30].

The practical utility of the equation for neonatologists may be useful. Thoracic cavity abnormalities are usually detected in the neonatal period and often lethal [31] when they result in pulmonary hypoplasia. In these cases, $\mathrm{HC}$ or weight is not enough. This is because they are often associated with a small, narrow, elongated rib cage typical of abnormal rib development [32]. In this sense, the usefulness of detecting pathological CC as a spy of the chest malformation and/or as a dysmorphic feature may be important, if associated with clinical signs or in addition to other dysmorphic elements.

Another study [7] that discussed predictive equations involving CC investigated low-weight NB that were still hospitalized. The authors aimed at developing a simple, inexpensive and practical method to identify low-weight NB. Thus, the cutoff point used to detect low-weight NB would be $30.15 \mathrm{~cm}$ for CC and $33.25 \mathrm{~cm}$ for HC. However, given the better sensitivity observed, the measure of CC would be superior in detecting low-weight NB [7].

Bishnupada et al. [8] used anthropometric parameters, such as mid-upper-arm circumference, $\mathrm{CC}$ and $\mathrm{HC}$, to identify their relation with birth weight in $316 \mathrm{NB}$ in Dhaka, Bangladesh. The authors obtained an average birth weight of $2.889 \mathrm{~g}$, corresponding to $15.18 \%$ of lowweight babies $(<2.500 \mathrm{~g})$. Thus, sensitivity and specificity were considered better for $\mathrm{CC}$, which is the best detector of birth weight, with a correlation coefficient slightly above 0.84 when compared to the other anthropometric measures. In an observational study, Ramagopal Shastry, Poornima \& Bhat [1] also investigated the relation between birth weight and $\mathrm{HC}$, and arm circumference and $\mathrm{CC}$, with findings similar to ours.

In three regions of Himachal Pradesh, in India, a study was conducted to obtain a standard reference criterion (mean $\pm \mathrm{SD}$ ) for normal full-term NB parameters and the correlation between birth weight and $\mathrm{HC}, \mathrm{CC}$ and AC. Chest circumference was $31.1 \mathrm{~cm}$ in boys and 31.0 $\mathrm{cm}$ in girls, corroborating the findings of our study. Furthermore, $\mathrm{CC}$ showed a high correlation $(r=0.752)$ with $\mathrm{AC}$, compared with other anthropometric parameters according to birth weight. It was also observed that $\mathrm{CC}$ and $\mathrm{AC}$ showed greater correlation $(\mathrm{r}=0.785)$ in Himachal Pradesh, $(r=0.752)$ the outer Himalaya and $(r=$ 0.848 ) and the middle Himalaya. However, these findings exhibit some limitations, related to differences in genetic, nutritional and environmental factors when compared to the Brazilian population [33].
It is important to underscore that the high rate of cesarean deliveries in the present study is associated with insufficient dilation for natural childbirth, poor baby positioning and insufficient uterine dynamics. Cesarean sections are prevalent in all parts of Brazil, accounting for approximately $50 \%$ of the babies delivered in the country [34]. The percentage in the study sample is a reflection of what is occurring throughout the country. According to the World Health Organization (WHO) cesarean deliveries should not exceed 15\%, and natural childbirth should be strongly promoted, with a focus on humanized care $[34,35]$.

In this respect, it is important to underscore the importance of the association between anthropometric variables in assessing child development in order to construct reliable indicators, corroborating the findings of the present study. Ndu et al. [36] took anthropometric measures (CC and $\mathrm{HC}$ ) to detect low birth weight among NB from the Igbo people of Nigeria. These authors also found $\mathrm{CC}$ to be the best predictor to detect low-birth-weight babies, indicating that $\mathrm{CC}$ is a strong marker of development.

It is important to emphasize that variations in $\mathrm{CC}$ have been little studied in Brazil. Pediatric health care teams need more information on changes in $\mathrm{CC}$, establishing the predictive equation, and standardizing measures to assess a child's developmental progress, in order to identify the responses to extrinsic factors related to nutrition, growth and development.

In this respect, studies that provide a more detailed description of these measures, comparability and, especially, research involving interventions aimed specifically at improving nutritional and motor indicators should be encouraged. It is suggested that the CC percentiles of healthy term newborns be calculated in the future.

The present study exhibits limitations. For example, the sample size is considered small for the type of study, showing the need for new investigations with larger sample sizes, as well as including premature newborns.

\section{Conclusions}

There is a positive correlation between CC and weight, length and $\mathrm{HC}$. However, after adjusting for covariables, only $\mathrm{HC}$ and weight predicted CC. It is important to underscore the importance of knowledge regarding the main aspects related to the development and growth of NB. As such, neonatal and pediatric health professionals should consider these measures in order to provide comprehensive care to children, who should also be periodically monitored.

\section{Abbreviations}

AC: Abdominal circumference; CC: Chest circumference; Cl: Confidence interval; DBP: Diastolic blood pressure; GA: Gestational age; HC: Head circumference; HR: Heart rate; NB: Newborn; NICU: Neonatal intensive care 
unit; RR: Respiratory rate; SBP: Systolic blood pressure; SPSS: Statistical package for the social sciences; WHO: World Health Organization

\section{Acknowledgements}

We want to acknowledge the Ana Bezerra University Hospital, RN, Brazil.

\section{Authors' contributions}

IGA, NSOH and SAP were responsible for study ideation and design of the work; IGA was responsible for statistical analysis; $\mathrm{NSOH}$ wrote the initial version of the paper; SAP, IGA and NMRA reviewed and contributed to the writing of the final version of the paper. AGFA and RTGS participated in the collection of data. All the authors read and approved the final version of the manuscript.

\section{Funding}

This research did not receive any specific grant from funding agencies in the public, commercial, or not-for-profit sectors.

\section{Availability of data and materials}

The dataset used and analyzed during the current study is available from the corresponding author on reasonable request.

\section{Ethics approval and consent to participate}

The study protocol was approved by local ethical committees (Committee of the Federal University of Rio Grande do Norte - UFRN). The reference number for the ethics committee is 2.116.308, CAAE: 36086614.2 .0000 .5568 . The committee evaluated the ethical aspects of the study in accordance with The World Medical Association's Declaration of Helsinki. The study was explained in detail to the participants' parents. Parental written informed consent was obtained right before patient enrollment in all cases.

\section{Consent for publication}

Not applicable.

\section{Competing interests}

The authors declare that they have no competing interests.

\section{Author details}

${ }^{1}$ Ana Bezerra University Hospital - Empresa Brasileira de Serviços Hospitalares, Federal University of Rio Grande do Norte (UFRN), Praca Tequinha Farias, 13, Santa Cruz, RN 59200-000, Brazil. 'Faculty of Health Sciences, Federal University of Rio Grande do Norte (FACISA - UFRN), Rua Teodorico Bezerra, Santa Cruz, RN 59200-000, Brazil. ${ }^{3}$ Department of Pediatrics, Federal University of Rio Grande do Norte (UFRN), Campus Universitário Lagoa Nova, Natal, RN 59078-970, Brazil. ${ }^{4}$ Graduate Pediatrics and Applied Sciences in Pediatrics Program, Federal University of São Paulo (UNIFESP), São Paulo, SP Brasil. ${ }^{5}$ Postgraduated Program in Rehabilitation Science - FACISA - UFRN, Santa Cruz, Brazil. ' Department of Physical therapy and Postgraduated Program in Rehabilitation Science - FACISA, Federal University of Rio Grande do Norte UFRN, Campus Universitário Lagoa Nova - CEP 59078-970, Natal, RN Caixa Postal 1524, Brazil.

Received: 27 December 2018 Accepted: 5 September 2019 Published online: 26 September 2019

\section{References}

1. Ramagopal Shastry CK, Poornima RB. Anthropometric measurements of newborns. Int J Contemp Pediatr. 2015;2:85-9.

2. Sreeramareddy $C T$, Chuni N, Patil R, Singh D, Shakya B. Anthropometric surrogates to identify low birth weight Nepalese newborns: a hospitalbased study. BMC Pediatr. 2008;8(16):1-6.

3. Naik DB, Kulkarni AP, Aswar NR. Birth weight and anthropometry of newborns. Indian J Pediatr. 2003;70:145-6.

4. Hossain MM, Habib M, DuPont HL. Association between birth weight and birth arm circumference of neonates in rural Egypt. Indian J Pediatr. 1994:61:81-7.

5. Magalhães EIS, Sant'Ana LFR, Priore SE, Franceschini SCC. Waist circumference, waist/height ratio, and neck circumference as parameters of central obesity assessment in children. Rev Paul Pediatr. 2014;32:273-81.

6. Sajjadian N, Shajari H, Rahimi F, Jahadi R, Barakat MG. Anthropometric measurements at birth as predictor of low birth weight. 2011;3(12):752-6.
7. Hadush MY, Berhe AH, Medhanyie AA. Foot length, chest and head circumference measurements in detection of low birth weight neonates in Mekelle, Ethiopia: a hospital based cross sectional study. BMC Pediatr. 2017; 17(111):1-8.

8. Bishnupada D, Golam M, Shamsun N, Nazrul I. Birth-weight status of newborns and its relationship with other anthropometric parameters in a public maternity hospital in Dhaka. Bangladesh J Health Populnutr. 2002; 20(1):36-41.

9. WHO. Use of a simple anthropometric measurement to predict birth weight. WHO Collaborative Study of Birth Weight Surrogates. Bull World Health Organ. 1993;71:157-63.

10. Jaldin MGM, Pinheiro FS, Santos AM, Muniz NC, Brito LMO. Crescimento do perímetro cefálico nos primeiros seis meses em crianças em aleitamento materno exclusivo. Rev Paul Pediatr. 2011;29(4):509-14.

11. Huang $X Y$, Liu HL, Lei M, Mai HF, Lian CH, Li YC. Intrauterine growth curves for body weight, body length, head circumference, chest circumference, and crown-rump length in 16887 neonates with a gestational age of 27-42 weeks in Shenzhen, China. Zhongguo Dang Dai Er Ke Za Zhi. 2017;19(8):877-86.

12. Zhang Y, Zhou J, Niu F, Donowitz JR, Haque R, PetriJr WA, et al. Characterizing early child growth patterns of height-for-age in an urban slum cohort of Bangladesh with functional principal component analysis. BMC Pediatr. 2017;17:84

13. Avaliação nutricional da criança e do adolescente - Manual de Orientação/ Sociedade Brasileira de Pediatria. Departamento de Nutrologia. São Paulo: Sociedade Brasileira de Pediatria. Departamento de Nutrologia, 2009. 112 p.

14. Simplício MPT, Ribeiro AQ, Sant'Ana LFR, Novaes JF, Priore SE, Franceschini SCC. Curvas de crescimento e perfil dietético de recém-nascidos pré-termo com peso adequado para a idade gestacional durante a hospitalização. Rev Paul Pediatr. 2012;30(3):359-68.

15. Tremblay G, Boudreau C, Bélanger S, St-Onge O, Pronovost E, Simonyan D, et al. Body composition in very preterm infants: role of neonatal characteristics and nutrition in achieving growth similar to term infants, Neonatology. 2017;111:214-21.

16. Barreto GMS, Balbo SL, Rover MS, Toso BRGO, Oliveira HR, Viera CS. Growth and biochemical markers of preterm newborns up to six months of corrected age. J Hum Growth. 2018:28(1):18-26.

17. Dimeglio A, Canavese F. The growing spine: how spinal deformities influence normal spine and thoracic cage growth. Eur Spine J. 2012;21(1): 64-70.

18. Tzarouchi LC, Drougia A, Zikou A, Kosta P, Astrakas LG, Andronikou S, et al. Body growth and brain development in premature babies: an MRI study. Pediatr Radiol. 2014;44(3):297-304.

19. Silva VM, Lopes MVO, Araujo TL. Evaluation of the growth percentiles of children with congenital heart disease. Rev Latino-am Enfermagem. 2007 15(2):298-303.

20. Vieira MA, Lima RAG. Crianças e adolescentes com doença crônica: convivendo com mudanças. Rev Latino-am Enfermagem. 2002;10(4):552-60.

21. Jansen FAR, Van Zwet EW, Rijlaarsdam MEB, Pajkrt E, Van Velzen CL, Zuurveen HR, et al. Head growth in fetuses with isolated congenital heart defects: lack of influence of aortic arch flow and ascending aorta oxygen saturation. Ultrasound Obstet Gynecol. 2016:48:357-64.

22. Agrasada GV, Ewald U, Kylberg E, Gustafsson J. Exclusive breastfeeding of low birth weight infants for the first six months: infant morbidity and maternal and infant anthropometry. Asia Pac J Clin Nutr. 2011; 20(1):62-8.

23. Patsourou A, Konstantinides T, Mantadakis E, Tsalkidis A, Zarras C, Balaska A, et al. Growth of exclusively breastfed and self-weaned children of Greece aged 0-36 months. Breastfeed Med. 2012;7(6):521-5.

24. Streja E, Miller JE, Wu C, Bech BH, Pedersen LH, Schende DE, et al. Disproportionate fetal growth and the risk for congenital cerebral palsy in singleton births. PLoS One. 2015;10(5):1-14.

25. Santos NF, Costa RA. Consumo de tabaco parental e desenvolvimento infantil. J Pediatr. 2015;91(4):366-72

26. Rover MMS, Viera CS, Silveira RC, Guimarães ATB, Grassiolli S. Fatores de risco associados à falha de crescimento no seguimento de recém-nascidos de muito baixo peso. J Pediatr. 2016:92(3):307-13.

27. Formiga CKMR. Crescimento e Desenvolvimento Neuropsicomotor de Crianças de Zero a Dois Anos. Pediatr Mod. 2015:51(11):405-10.

28. Salge AKM, Rocha EL, Gaíva MAM, Castral TC, Guimarães JV, Xavier RM. Foot length measurements of newborns of high and low risk pregnancies. Rev Esc Enferm USP. 2017;51:e3200. 
29. Lei XP, Zhang YJ, Fang F, Wu T, Chen Y, Zhang J. Choosing the best newborn anthropometric measure associated with the risks and outcomes of intrauterine growth restriction. Clin Pediatr. 2015;54(14):1315-21.

30. Nayak CD, Agarwal V, Nayak DM. Correlation of cord blood lipid heterogeneity in neonates with their anthropometry at birth. Ind I Clin Biochem. 2013;28(2):152-7.

31. Poyner SE, Bradshaw WT. Jeune syndrome: considerations for management of sphyxiating thoracic dystrophy. Neonatal Netw. 2013;32(5):342-52.

32. Orfaliais CS, March MF, Ferreira S, Alves R, Sant'Anna CC. Asphyxiating thoracic dystrophy: a report of 3 cases. J Pediatr. 1998;74(4):333-7.

33. Pankaj S, Kanchan K. Correlation of birth weight with other anthropometric parameters of newborns in Himachal Pradesh. Int J Cur Res Rev. 2017;9:49-54

34. Rattner D, Moura EC. Nascimentos no Brasil: associação do tipo de parto com variáveis temporais e sociodemográficas. Rev Bras Saúde Matern Infant. 2016;16(1):39-47.

35. Saraiva JM, Gouveia HG, Gonçalves AC. Fatores associados a cesáreas em um hospital universitário de alta complexidade do sul do Brasil. Rev Gaúcha Enferm. 2017;38(3):e69141.

36. Ndu IK, Ibeziako SN, Obidike EO, Adimora GN, Edelu BO, Chinawa JM, et al. Chest and occipito-frontal circumference measurements in the detection of low birth weight among Nigerian newborns of Igbo ethnicity. Ital J Pediatr. 2014;40:81.

\section{Publisher's Note}

Springer Nature remains neutral with regard to jurisdictional claims in published maps and institutional affiliations.

Ready to submit your research? Choose BMC and benefit from:

- fast, convenient online submission

- thorough peer review by experienced researchers in your field

- rapid publication on acceptance

- support for research data, including large and complex data types

- gold Open Access which fosters wider collaboration and increased citations

- maximum visibility for your research: over $100 \mathrm{M}$ website views per year

At BMC, research is always in progress.

Learn more biomedcentral.com/submissions 